\title{
Pengaruh penambahan Aspergillus niger Iradiasi Sinar Gamma Dosis Rendah pada Jerami Padi Fermentasi dan Evaluasi Kualitasnya sebagai Pakan Ternak Ruminansia Secara In Vitro
}

\section{Effects of Aspergillus niger Irradiation Low Dose Gamma Rays on Fermented Rice Straw and Evaluation of Quality as Ruminant Livestock Feed by In Vitro Method}

\author{
Crhisterra E. Kusumaningrum ${ }^{1}$, Shintia Nugrahini W.H. ${ }^{1}$, Arthalia Poetri \\ Yunisa $^{2}$, Nana Mulyana ${ }^{1}$ dan Suharyono ${ }^{1}$ \\ ${ }^{1}$ Pusat Aplikasi Isotop dan Radiasi, BATAN \\ Jalan Lebak Bulus Raya 49, Jakarta Selatan, 12440 \\ ${ }^{2}$ Fakultas Sains dan Teknologi, Universitas Islam Negeri, Syarif Hidayatullah \\ Jl. Ir. H. Juanda No. 95, Tangerang Selatan, Banten, 15412 \\ Email : ellen@batan.go.id
}

\begin{abstract}
ABSTRAK
Penelitian dilakukan untuk mengetahui pengaruh pemberian Aspergillus niger iradiasi sinar gamma dosis rendah pada jerami padi fermentasi dan potensinya sebagai pakan ternak ruminansia secara in vitro. Proses fermentasi dilakukan dengan teknik Solid State Fermentation (SSF) menggunakan A. niger yang diiradiasi sinar gamma dosis rendah untuk meningkatkan kemampuan memecah ikatan selulosa. Orientasi dosis iradiasi sinar gamma sebesar 0, 125, 250, 375, 500, 625 dan 750 Gy dilakukan pada $A$. niger untuk mengetahui kondisi yang optimum dalam menghasilkan aktivitas enzim selulase. A. niger iradiasi sinar gamma pada dosis yang optimum digunakan untuk pembuatan jerami padi fermentasi dan dilakukan evaluasi kemampuan jerami padi fermentasi sebagai pakan ternak ruminansia secara in vitro. Perlakuan jerami padi fermentasi yaitu P0. Jerami Padi, P1. Jerami padi fermentasi A. niger 0 Gy dan P2. Jerami padi fermentasi A. niger 500 Gy. Hasil menunjukkan bahwa dosis optimum iradiasi sinar gamma pada A. niger dalam menghasilkan enzim selulase $(3,24 \mathrm{U} / \mathrm{ml})$ adalah $500 \mathrm{~Gy}$. Pada jerami padi fermentasi A. niger 500 Gy menunjukkan aktivitas enzim selulase tertinggi yaitu sebesar 48,5384 U/g bahan kering (BK) dan kadar glukosa sebesar 247,33 mg/g BK pada hari ke-14. Proses fermentasi dengan A. niger iradiasi sinar gamma (500 Gy) mampu meningkatkan kandungan proein kasar, acid detergent fiber (ADF), neutral detergent fiber (NDF) dan bahan kering, namun menurunkan kandungan lemak kasar dan bahan organik (BO). Hasil fermentasi dalam cairan rumen dari jerami padi fermentasi dengan dengan A. niger iradiasi sinar gamma (500 Gy) menunjukkan nilai $\mathrm{pH}$ sebesar 7,01; konsentrasi ammonia dan volatile fatty acid (VFA) masing-masing sebesar 3,92\% dan 4,73 $\mathrm{mmol} / 100$.
\end{abstract}

Kata kunci : Jerami padi, A. niger, iradiasi gamma, fermentasi

\begin{abstract}
The study was conducted to determine the effect of A. niger irradiation of low-dose gamma rays on fermented rice straw and its potency as ruminants feed by in vitro method. The fermentation process was performed with Solid State Fermentation (SSF) technique using A. niger which irradiated low-dose gamma rays to improve the ability of breaking cellulose bonds. Orientation of gamma-ray irradiation doses of $0,125,250,375,500,625$ and 750 Gy was performed on A. niger to determine the optimum conditions in producing cellulase enzyme activity. A. niger gamma ray irradiation at the optimum dose was used for making fermented rice straw and evaluated the ability of fermented rice straw as ruminants feed by in vitro method. The treatment of fermented rice straw is P0. Rice Straw, P1. Fermented rice straw A. niger 0 Gy and P2. Fermented rice straw A. niger $500 \mathrm{~Gy}$. The results showed that the optimum dose of gamma ray irradiation on A. niger in producing cellulase enzyme $(3.24 \mathrm{U} / \mathrm{ml})$ was $500 \mathrm{~Gy}$. In A. niger 500 Gy fermented rice straw showed cellulase enzyme activity of 48,5384 U / g dry matter (DM) and glucose level of $247.33 \mathrm{mg} / \mathrm{g}$ DM. Fermentation process with A. niger gamma ray irradiation (500 Gy) can increase the content of crude proein, acid detergent fiber (ADF), neutral detergent fiber (NDF) and dry ingredients, but decrease crude fat content and organic matter (OM). The results of fermentation in rumen fluid from fermented rice straw with A. niger gamma ray irradiation (500 Gy) showed a $\mathrm{pH}$ value of 7.01;
\end{abstract}


the concentrations of ammonia and volatile fatty acids (VFAs) were $3.92 \%$ and $4.73 \mathrm{mmol} / 100$, respectively.

Keywords: Rice straw, A. niger, gamma irradiation, fermentation

\section{PENDAHULUAN}

Jerami padi merupakan limbah pertanian terbesar di Indonesia, yang produksinya mencapai 12-15 ton/ha/panen, tergantung pada lokasi dan varietas padi yang ditanam. Biomassa lignoselulosa dari jerami padi mengandung 41,3\% selulosa; $20,4 \%$ hemiselulosa dan $12,1 \%$ lignin [1]. Pemanfaatan jerami padi biasanya digunakan untuk pakan ternak dan industri yang masingmasing sebesar $31-39 \%$ dan $7-16 \%$, yang lainnya untuk pupuk atau dibakar. Sebagai pakan ternak, jerami padi mempunyai kandungan nutrisi protein kasar yang rendah yaitu sekitar 3-5\% dan serat kasar yang tinggi yaitu lebih dari $34 \%$. Selain itu ikatan lignoselulosanya kuat dan kecernaan rendah. Kandungan serat kasar yang tidak dapat dicerna akibat lignifikasi selulosa tinggi menyebabkan tingkat kecernaan menurun. Oleh karena itu diperlukan suatu teknologi yaitu teknologi fermentasi untuk meningkatkan kandungan nutrisi jerami padi. Komposisi nutrisi jerami padi yang telah difermentasi dengan menggunakan $A$. niger, memperlihatkan peningkatan nilai proksimat dibanding jerami padi yang tidak difermentasi. Lebih lanjut dijelaskan kadar protein kasar jerami padi yang difermentasi dengan $A$. niger mengalami peningkatan dari $5,01 \%$ menjadi $7,54 \%$ dan diikuti penurunan serat kasar [2].

Metode fermentasi yang digunakan merupakan metode Solid State Fermentation (SSF). Metode SSF adalah metode fermentasi yang substratnya tidak larut dan tidak mengandung air bebas tetapi cukup mengandung air untuk keperluan mikroba. Media berfungsi sebagai sumber karbon, nitrogen maupun sumber energi [3]. Pada metode SSF ini menggunakan strain yang mampu mendegradasi selulosa yaitu $A$. niger. A. niger menghasilkan enzim selulolitik yang mampu mengkatalisis reaksi hidrolisis kristal selulosa. Enzim selulase yang dihasilkan oleh bakteri dan fungi di dalam fermentasi mampu memecah ikatan b-1,4 glukosida menjadi monomer glukosa. Penelitian sebelumnya menyatakan bahwa sakarifikasi enzimatis menggunakan enzim selulase kasar dari A. niger pada ampas tebu terdelignifikasi menghasilkan gula reduksi sebesar 54,47 mg/100 ml [4].

Proses fermentasi ini menggunakan strain yang diiradiasi dengan sinar gamma untuk meningkatkan aktivitas selulase dalam mendegradasi selulosa. Radiasi sinar gamma $\left({ }^{60} \mathrm{Co}\right)$ dapat meningkatkan aktivitas spesifik selulase dari Aspergillus sp. pada medium fermentasinya. Lebih lanjut dijelaskan peningkatan aktivitas enzim akibat iradiasi karena teknik ini mempunyai kemampuan merusak struktur sel tumbuhan, sehingga menyebabkan enzim yang terdapat pada struktur internal akan bersinggungan secara langsung dengan substrat yang digunakan. Hal ini dapat menyebabkan perubahan fisiologis sel, seperti peningkatan aktivitas enzim yang cukup besar [5]. Oleh karena itu dalam penelitian ini dilakukan proses fermentasi jerami padi dengan $A$. niger yang diiradiasi dengan sinar gamma yang diharapkan mampu menghasilkan kualitas pakan ternak yang lebih baik daripada jerami padi kering tanpa fermentasi. Indikator untuk mengetahui aktivitas fermentasi oleh $A$. niger yang diiradiasi dosis rendah adalah dengan mengamati aktivitas enzim dan kandungan nutrisi dari jerami padi. Tujuan penelitian ini adalah untuk menentukan kualitas jerami padi hasil fermentasi dengan $A$. niger yang diiradiasi sinar gamma dosis rendah sebagai pakan ternak ruminansia secara in vitro.

\section{BAHAN DAN METODE}

Kegiatan penelitian dilakukan dalam tiga tahapan. Tahap pertama yaitu orientasi dosis iradiasi sinar gamma pada $A$. niger. Tahap kedua yaitu fermentasi jerami padi menggunakan $A$. niger iradiasi sinar gamma dosis optimum pada tahap pertama. Tahap ketiga yaitu evaluasi jerami padi fermentasi sebagai pakan ternak secara in vitro.

\section{Orientasi dosis}

Kultur A. niger merupakan koleksi kelompok lingkungan, Bidang Industri dan Lingkungan. Pusat Aplikasi Isotop dan Radiasi- 
Badan Tenaga Nuklir Nasional (PAIR-BATAN). Kultur A. niger murni dikultivasikan pada larutan Potato Dextrose Broth (PDB) yang dibuat dengan melarutkan sebanyak 5,3 gram PDB dalam $200 \mathrm{ml}$ akuades. Kemudian diinkubasi dengan cara dikocok menggunakan stirer selama $3 \times 24$ jam. Kultur A. niger tersebut selanjutnya dikultivasikan pada media Potato Dextrose Agar (PDA) yang dibuat dengan mencampurkan 5,3 gram PDB, 200 $\mathrm{ml}$ akuades dan agar supaya menjadi padatan. Kultur tersebut dikultivasikan dalam cawan petri, kultur disebar merata dan diinkubasi selama 3 hari. Kultur yang tumbuh dikultivasikan kembali dalam agar miring untuk selanjutnya dilakukan proses iradiasi menggunakan Iradiator Gamma Chamber 4000A dengan dosis 0, 125, 250, 375, 500,625 dan 750 Gy untuk mengetahui dosis yang optimum dalam menghasilkan enzim selulase.

\section{Fermentasi jerami padi dengan $A$. niger}

Jerami padi diperoleh dari Pusat Aplikasi Isotop dan Radiasi - BATAN dengan nama varietas SiDenuk. Jerami padi dibersihkan dan dikeringkan selama 1-2 hari, kemudian dicacah dengan menggunakan chopper mekanik. Sebelum proses fermentasi, jerami padi diberi perlakuan perendaman menggunakan larutan $\mathrm{NaOH} 1 \%$. Sebanyak $1,9 \mathrm{~kg}$ jerami padi direndam dengan menggunakan larutan $\mathrm{NaOH} 1 \%$ sebanyak $500 \mathrm{ml}$ selama 1 jam. Setelah direndam dengan $\mathrm{NaOH}$, jerami padi dicuci dengan menggunakan air, lalu diperas airnya. Selanjutnya jerami padi ditiriskan, dikeringkan dalam oven dan digiling menjadi serbuk (substrat jerami padi).

Perlakuan jerami padi fermentasi yaitu P0. Jerami Padi, P1. Jerami padi fermentasi A. niger 0 Gy dan P2. Jerami padi fermentasi A. niger 500 Gy. Proses fermentasi jerami padi didasarkan pada metode Pensupa et al., (2013) [6] yang dimulai dengan membuat $4500 \mathrm{~mL}$ larutan nutrisi yang terdiri dari $\mathrm{MnSO}_{4}(1,52 \mathrm{~g} / \mathrm{l}), \mathrm{CuSO}_{4}(1,91 \mathrm{~g} / \mathrm{l})$, $\mathrm{ZnSO}_{4}(2,15 \mathrm{~g} / \mathrm{l}), \mathrm{H}_{3} \mathrm{BO}_{3}(1,39 \mathrm{~g} / \mathrm{l}), \mathrm{KH}_{2} \mathrm{PO}_{4}(1,47$ $\mathrm{g} / \mathrm{l}), \mathrm{MgSO}_{4} \cdot 7 \mathrm{H}_{2} \mathrm{O}(0,24 \mathrm{~g} / \mathrm{l}),\left(\mathrm{NH}_{4}\right)_{2} \mathrm{SO}_{4}(0,98 \mathrm{~g} / \mathrm{l})$ dan asam sitrat $(24,46 \mathrm{~g} / \mathrm{l})$. Dalam 50 gram substrat jerami padi, ditambahkan $100 \mathrm{ml}$ larutan nutrisi, kemudian diaduk merata dan dimasukkan dalam wadah toples lalu disterilkan dengan autoklaf pada $121^{\circ} \mathrm{C}$ selama $2 \times 15$ menit. Diinokulasikan $25 \mathrm{ml}$ kultur cair A. niger ke dalam substrat jerami padi steril. Selanjutnya dilakukan fermentasi di ruang gelap pada suhu ruang selama 21 hari. Pengukuran dilakukan pada beberapa parameter diantaranya, pengukuran aktivitas enzim selulase yang diakukan pada hari ke $0,7,14$ dan 21 [7], pengukuran kandungan glukosa pada hari ke 0, 7, 14 dan 21 [8,9], pengukuran $\mathrm{pH}$, dan pengukuran bobot biomassa fungi [10].

\section{Evaluasi jerami padi fermentasi sebagai pakan ternak secara in vitro}

Fermentasi jerami padi yang telah jadi dimanfaatkan untuk mengetahui sejauh mana jerami tersebut berpotensi sebagai pakan ternak ruminansia. Pada tahap ini, dilakukan pengukuran kandungan nutrisi dengan metode analisis proksimat. Parameter kandungan nutrisi yang dinalisis adalah kadar lemak kasar [11], pengukuran Acid Detergent Fiber (ADF) dan Neutral Detergent Fiber (NDF) [12], pengukuran kadar Protein Kasar [13], pengukuran kadar Bahan Kering (BK) dan Bahan Organik (BO) [14]. Evaluasi dilakukan secara in vitro dengan menggunakan inkubator pada suhu $37-39^{\circ} \mathrm{C}$. Sampel jerami padi fermentasi sebanyak $250 \mathrm{mg}$ dimasukkan ke dalam tabung sentrifugasi. Kemudian ditambahkan cairan rumen kerbau sebanyak $20 \mathrm{ml}$ yang diambil dari kerbau yang difistula dan disaring dengan kain kasa 4 lapis. Selanjutnya tabung sentrifugasi tersebut diinkubasi pada inkubator suhu $37-39^{\circ} \mathrm{C}$ selama 2 jam dan diukur nilai $\mathrm{pH}$, ammonia dan TVFA.

\section{HASIL DAN PEMBAHASAN}

\section{Orientasi dosis}

A. niger merupakan suatu mikroorganisme dari kapang (fungi) yang sangat berpotensi mengeksresikan enzim selulase yang mampu menghidrolisa selulosa dan lignin. Hasil hidrolisis akan bermanfaat sebagai pakan ternak dan energi [15]. Hasil pengamatan dengan iradiasi dosis rendah $(0,125,250,375,500,625$ dan $750 \mathrm{~Gy})$ terlihat bahwa dosis 500 Gy pada A. niger memberikan respon yang paling tinggi pada aktivitas enzim selulase jika dibanding dengan dosis paparan lainnya yaitu $3,24 \mathrm{U} / \mathrm{ml}$ dibanding masing-masing hanya 0,$8 ; 0,45 ; 1,2 ; 2,1 ; 1,5$ dan 2 $\mathrm{U} / \mathrm{ml}$ (Gambar 1).

Perlakuan dari gamma iradiasi pada $A$. niger menyebabkan peningkatan kecernaan bahan organik karena dinding sel dari bahan tersebut terdegradasi dan akan menghasilkan produk- 
produk yang bermanfaat [16] yang disitasi oleh (Betiku et al., 2010).

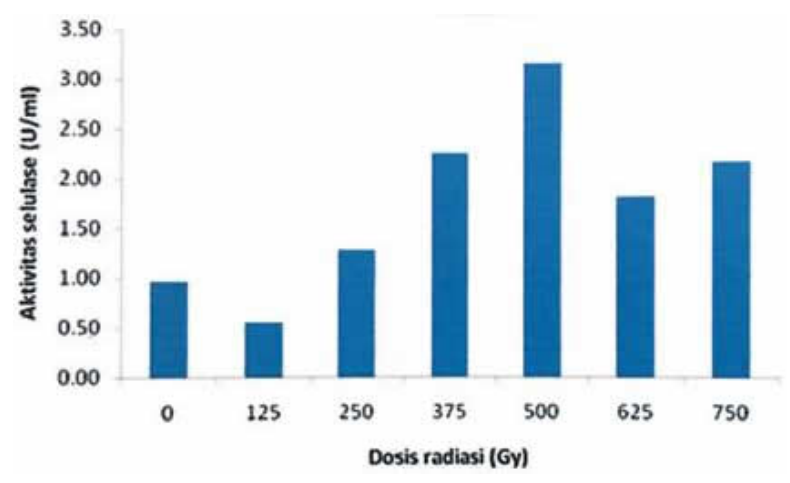

Gambar 1. Grafik aktivitas enzim selulase pada orientasi dosis

\section{Fermentasi jerami padi dengan $A$. niger}

\section{Aktivitas enzim selulase}

Hasil pengamatan aktivitas enzim selulase dapat dilihat pada Gambar 2. Hari ke-14 merupakan waktu yang paling optimal bagi fungi dalam memproduksi enzim selulase. Hal ini terlihat dari hasil penelitian yang memperlihatkan bahwa jerami yang difermentasi A. niger 500 Gy pada hari ke-14 mampu menghasilkan enzim selulase yang paling tinggi yaitu sebesar 48,54 U/g DM. Sesuai yang dikemukakan oleh Afify et al, (2012) [5] bahwa pada hari ke-14 kemampuan Trichoderma viride dalam mendegradasi karbofuran dalam tanah sangat baik yaitu sebesar $86 \%$.

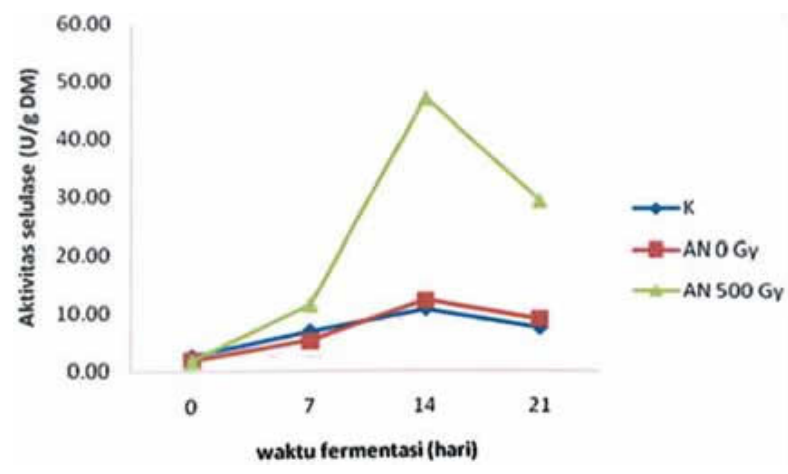

$\mathrm{P} 0=\mathrm{K} \quad=$ Kontrol (jerami padi kering

$\mathrm{P} 1=\mathrm{AN} 0 \mathrm{~Gy} \quad=$ Jerami padi fermentasi A.Niger 0 Gy

$\mathrm{P} 2=\mathrm{AN} 500 \mathrm{~Gy}=$ Jerami padi fermentasi A.Niger $500 \mathrm{~Gy}$

Gambar 2. Aktivitas enzim selulase pada proses fermentasi jerami padi
Fungi $T$. viride dan A. niger merupakan fungi yang masih berada dalam satu kingdom. Selain menghasilkan enzim yang dapat menghidrolisis selulosa menjadi glukosa, A. niger juga mampu mendegradasi lignin [17]. Hal ini akan memudahkan ikatan selulosa terdegradasi oleh enzim selulase secara optimal. Pada hari ke21 aktivitas enzim selulase jerami fermentasi 500 Gy menurun sekitar 18\% menjadi 30,26 U/ g bahan kering (BK). Jerami padi fermentasi 0 Gy dan jerami padi kering $(\mathrm{K})$ masing-masing hanya memproduksi enzim sebesar 9,23 U/ g BK dan 7,59 U/ g BK. Menurunnya aktivitas enzim selulase pada hari ke-21 diduga karena A. niger sudah tidak optimal dalam menghasilkan enzim selulase sehingga grafik tampak menurun. Hal tersebut terkait dengan fase pertumbuhan pada $A$. niger, dimana kemungkinan $A$. niger telah masuk pada fase kematian yang menyebabkan $A$. niger tidak mampu memproduksi enzim selulase secara optimal.

\section{Kadar glukosa}

Hasil evaluasi uji kandungan glukosa juga menunjukkan hasil fermentasi yang optimal pada hari ke-14. Hal ini tergambar dalam Gambar 3.

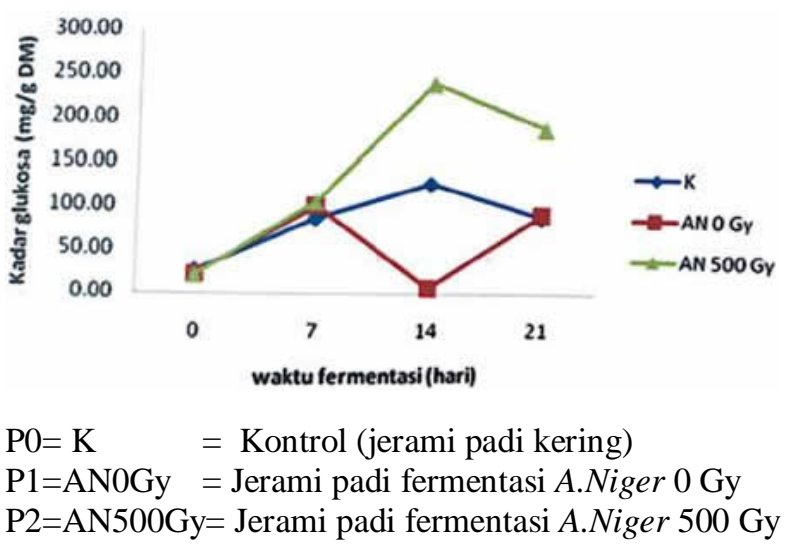

Gambar 3. Kadar glukosa pada proses fermentasi jerami padi

Grafik di atas memperlihatkan bahwa semua sampel sampai pada hari ke-7 tidak terdapat perbedaan yang signifikan. Pada hari ke14 merupakan waktu yang optimal untuk A. niger dalam menghasilkan jumlah glukosa paling banyak yaitu $247,33 \mathrm{mg} / \mathrm{g}$ BK pada jerami padi fermentasi A. niger 500 Gy. Meningkatnya kadar glukosa pada hari ke-14 berbanding lurus dengan kemampuan A. niger dalam menghasilkan enzim selulase seperti terlihat pada grafik aktivitas enzim 
selulase (Gambar 2.), yang optimum dihasilkan oleh A. niger pada hari ke-14. Sedangkan pada jerami $A$. niger 0 Gy terjadi penurunan kadar glukosa yang cukup signifikan dengan hanya memproduksi glukosa sebesar $6,95 \mathrm{mg} / \mathrm{g}$ BK karena diduga sebagian glukosa dikonsumsi oleh A. niger untuk dimetabolisme sebagai bagian dari adanya aktivitas fungi. Seperti yang dikemukakan oleh Fardiaz (1988) [18] bahwa selama fermentasi berlangsung, karbohidrat digunakan oleh mikroorganisme sebagai sumber energi.

\section{Derajat keasaman (pH)}

Pengukuran $\mathrm{pH}$ pada saat fermentasi menunjukkan bahwa proses fermentasi berjalan dengan baik, seperti yang terlihat pada Gambar 4 .

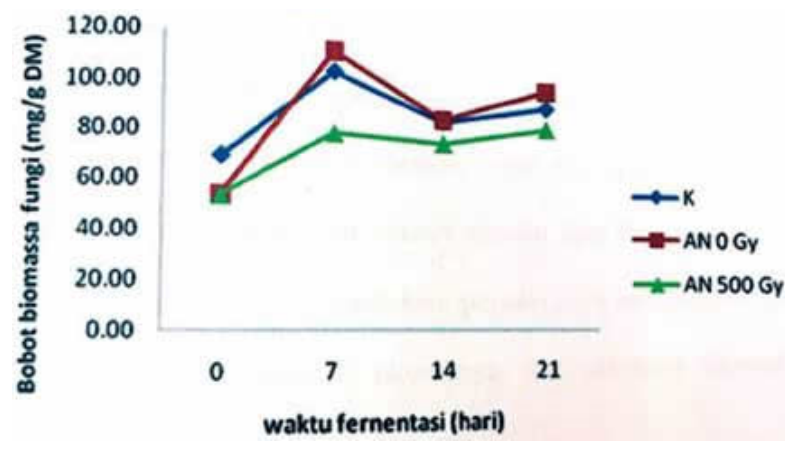

$\mathrm{P} 0=\mathrm{K} \quad=$ Kontrol (jerami padi kering)

$\mathrm{P} 1=\mathrm{ANOGy}=$ Jerami padi fermentasi A.Niger $0 \mathrm{~Gy}$

$\mathrm{P} 2=\mathrm{AN} 500 \mathrm{~Gy}=$ Jerami padi fermentasi A.Niger $500 \mathrm{~Gy}$

Gambar 4. Hasil pengukuran $\mathrm{pH}$ fermentasi jerami padi

Hasil pengamatan memperlihatkan bahwa jerami padi fermentasi dengan dosis iradiasi 500 Gy memiliki pH pada hari ke-14 yaitu sebesar 6,96. Hal ini membuktikan bahwa proses fermentasi berjalan dengan baik karena umumnya fungi dapat hidup optimal pada $\mathrm{pH}$ dibawah 7 . Sedangkan pada jerami fermentasi 0 Gy pada hari ke-14 memiliki pH sebesar 7,46. Hal ini diduga karena aktivitas metabolisme $A$. niger dan kadar glukosa sedang menurun sehingga dapat diasumsikan bahwa $A$. niger dalam jerami fermentasi 0 Gy pada hari ke-14 berada pada kondisi kurang optimal.

\section{Bobot biomassa fungi}

Perhitungan jumlah pertumbuhan fungi dilakukan dengan cara mengamati bobot biomassa fungi. Hasil pengukuran dapat dilihat pada Gambar 5.

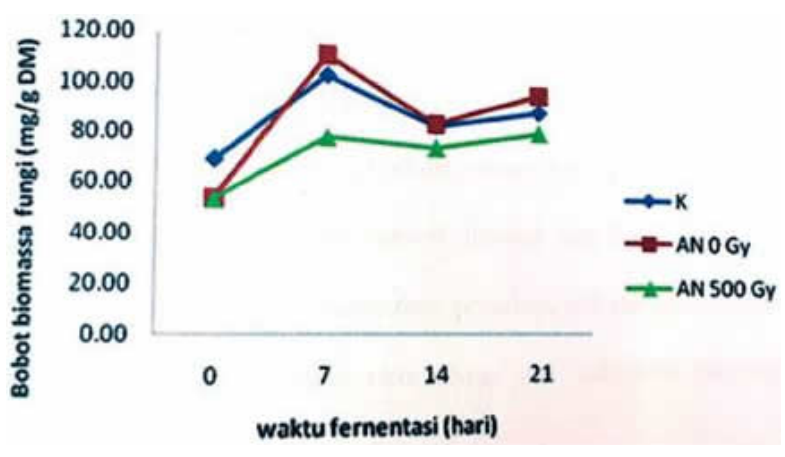

$\mathrm{P} 0=\mathrm{K} \quad=$ Kontrol (jerami padi kering)

$\mathrm{P} 1=\mathrm{AN} 0 \mathrm{~Gy} \quad=$ Jerami padi fermentasi A.Niger $0 \mathrm{~Gy}$

$\mathrm{P} 2=\mathrm{AN} 500 \mathrm{~Gy}=$ Jerami padi fermentasi A.Niger 500 Gy

Gambar 5. Bobot biomassa fungi proses fermentasi jerami padi

Dari hasil pengamatan dapat dilihat bahwa pertumbuhan mikroba tertinggi terjadi pada fermentasi jerami padi hari ke-7, dimana bobot biomassa fungi mengalami kenaikan sebesar 25$60 \%$. Jerami padi fermentasi 0 Gy memiliki nilai bobot biomassa fungi tertinggi pada hari ke-7 yaitu sebesar 113,32 mg/g BK. Sedangkan jerami padi fermentasi 500 Gy memiliki bobot biomassa fungi sebesar $79,72 \mathrm{mg} / \mathrm{g}$ BK dan jerami padi kering (K) sebesar 104,82\%. Jerami padi fermentasi menurun bobot biomassa fungi pada hari ke-14 sebesar 27\% dan penurunan 3\% pada jerami fermentasi 500 Gy. Pada hari ke 21 mengalami kenaikan. Ketidakstabilan pertumbuhan bakteri ini terkait dengan sistem metabolisme dalam bakteri itu sendiri antara lain $\mathrm{pH}$, penggunaan karbon dan sumber energi, efisiensi degradasi substrat, sintesis protein dan berbagai materi penyimpan serta pelepasan produk metabolisme dari dalam sel [19].

\section{Evaluasi jerami padi fermentasi sebagai pakan ternak secara in vitro}

\section{Kandungan nutrisi jerami padi}

Kandungan BK dan PK pada jerami fermentasi lebih tinggi daripada jerami tanpa fermentasi. Kandungan nutrisi jerami padi fermentasi A. niger iradiasi gamma $500 \mathrm{~Gy}$ dapat dilihat pada Tabel 1. Dari tabel 1 dapat dilihat nilai kandungan BK pada jerami fermentasi sebesar 95,38\% sedangkan pada jerami tanpa fermentasi sebesar 93,01\%. Sedangkan kandungan protein kasar pada jerami fermentasi sebesar 2,5\% dan jerami tanpa fermentasi sebesar 2,07\%. Hal ini disebabkan adanya proses penurunan kadar 
lignin pada jerami fermentasi. Penurunan kadar lignin akan membebaskan senyawa yang terikat ikatan kompleks lignoselulosa jerami padi yaitu nitrogen, mineral maupun selulosa, sehingga meningkatkan kandungan Bahan Kering dan Protein kasar dari jerami padi fermentasi $[20,21]$.

Tabel 1. Kandungan Nutrisi Jerami Padi

\begin{tabular}{lcc}
\hline $\begin{array}{c}\text { Komposisi } \\
\text { Nutrisi }\end{array}$ & $\begin{array}{c}\text { Jerami padi tanpa } \\
\text { fermentasi }\end{array}$ & $\begin{array}{c}\text { Jerami padi } \\
\text { fermentasi }\end{array}$ \\
\hline & $\%$ & $\%$ \\
\hline Lemak kasar & $1,19 \pm 1,37^{\mathrm{a}}$ & $1,12 \pm 0,26^{\mathrm{a}}$ \\
Protein kasar & $2,07 \pm 0,82^{\mathrm{a}}$ & $2,5 \pm 0,73^{\mathrm{ab}}$ \\
$\mathrm{ADF}$ & $67,50 \pm 1,91^{\mathrm{a}}$ & $70,51 \pm 3,38^{\mathrm{a}}$ \\
$\mathrm{NDF}$ & $89,27 \pm 9,81^{\mathrm{a}}$ & $93,73 \pm 3,32^{\mathrm{a}}$ \\
$\mathrm{BK}$ & $93,01 \pm 0,71^{\mathrm{ab}}$ & $95,38 \pm 0,14^{\mathrm{b}}$ \\
BO & $80,91 \pm 4,67^{\mathrm{a}}$ & $77,87 \pm 0,141^{\mathrm{a}}$ \\
Kadar Lignin & 16,69 & 12,68 \\
\hline
\end{tabular}

Superscript huruf yang sama pada baris yang sama menunjukkan tidak berbeda nyata $(\mathrm{P}>0,05)$; huruf yang berbeda pada baris yang sama menunjukkan berbeda nyata $(\mathrm{P}<0,05)$.

Proses fermentasi menurunkan kandungan Bahan Organik. Penurunan tersebut terjadi karena fungi memanfaatkan glukosa (sumber karbon) hasil hidrolisis enzimatik untuk memenuhi kebutuhan energi bagi pertumbuhan fungi melalui jalur glikolisis.

Proses fermentasi meningkatkan kandungan Neutral detergent fiber (NDF) dan Acid detergent fiber (ADF). Hal ini menunjukkan bahwa A. niger tidak mampu mendegradasi lignoselulosa dengan optimal sehingga kandungan NDF dan ADF tidak mengalami penurunan [21]. Selain itu, diduga lignin pada jerami padi tertutup oleh polysaccharide microfibers, struktur lignin cukup kompak, berbentuk kristal dan mengandung komplek yang heterogen. Kandungan lignin yang tinggi pada jerami padi akan menghambat enzim pada $A$. niger untuk mendegradasi lignoselulosa.

Hasil analisis oleh Velasquez (2015) [21], mengemukakan bahwa kandungan nutrisi dari jerami padi yang tidak difermentasi, kandungan BK $(96,3 \%)$, BO $(91,9 \%)$, protein kasar $(4 \%)$, $\operatorname{NDF}(86,2 \%)$ dan $\operatorname{ADF}(54,6 \%)$. Lebih lanjut disebutkan pula dengan perlakuan $A$. niger ternyata berbeda nyata pada $\mathrm{P}<0,05$ dari hasil pengamatan NDF dan ADF yang tanpa difermentasi $A n$ nilai masing-masing $85,55 \%$ dan $53,63 \%$, namun setelah difermentasi dengan $A$. niger hasilnya menurun masing-masing yaitu $61,74 \%$ dan $46,24 \%$. Penurunan ini disebabkan oleh menurunnya kandungan dinding sel khususnya fraksi ligninselulosa.

Nilai pH, kadar ammonia dan TVFA pada proses fermentasi dalam cairan rumen dapat dilihat pada Tabel 2. Berdasarkan hasil statistik menunjukkan bahwa semua perlakuan baik jerami kering, jerami fermentasi $A$. niger 0 Gy dan jerami fermentasi A. niger 500 Gy tampak tidak berbeda nyata $(\mathrm{P}>0,05)$. Namun secara numerik, nilai $\mathrm{pH}$ pada hasil penelitian berkisar antara 6,90-7,02. Nilai $\mathrm{pH}$ tersebut berada pada kisaran normal untuk pertumbuhan dan aktivitas mikroba rumen yaitu 6-7 [22].

Tabel 2. Hasil analisis uji in vitro

\begin{tabular}{llcl}
\hline Parameter & \multicolumn{3}{c}{ Perlakuan } \\
\hline & P0 & P1 & P2 \\
pH & 7,02 & 6,90 & 7,01 \\
Ammonia (\%) & 5,32 & 5,32 & 4,73 \\
TVFA (mmol/100) & 4,41 & 4,51 & 3,92 \\
\hline
\end{tabular}

$\mathrm{P} 0=\mathrm{K} \quad=$ Kontrol (jerami padi kering)

$\mathrm{P} 1=\mathrm{AN} 0 \mathrm{~Gy} \quad=$ Jerami padi fermentasi A.Niger 0 Gy

$\mathrm{P} 2=\mathrm{AN} 500 \mathrm{~Gy}=$ Jerami padi fermentasi A.Niger $500 \mathrm{~Gy}$

Kadar ammonia dan TVFA pada jerami padi fermentasi dengan dosis iradiasi 500 Gy mempunyai nilai terendah daripada jerami padi tanpa fermentasi dan jerami padi fermentasi dengan dosis iradiasi 0 Gy yaitu sebesar $4,73 \%$ dan 3,92 mmol/100. Hal ini disebabkan jumlah karbohidrat yang mudah terfermentasi meningkat sehingga mengakibatkan produksi ammonia turun, dimana terjadi peningkatan penggunaan amonia untuk sintesis protein mikroba. Aktivitas mikroba yang meningkat akan menyebabkan penggunaan $\mathrm{N}$-ammonia dan VFA meningkat pula, sehingga terjadi penurunan konsentrasi ammonia dan VFA. Kalbande dan Thomas (2001) [23] menyatakan bahwa ammonia akan digunakan oleh mikroba rumen untuk dikonversi menjadi protein mikroba dan VFA digunakan sebagai sumber energi dalam melakukan sintesis asam amino atau protein mikroba tersebut.

\section{KESIMPULAN}

Dosis optimum iradiasi sinar gamma pada A. niger dalam menghasilkan enzim selulase (3,24 $\mathrm{U} / \mathrm{ml}$ ) adalah $500 \mathrm{~Gy}$. Pada jerami padi fermentasi A. niger 500 Gy menunjukkan aktivitas enzim selulase tertinggi yaitu sebesar 48,5384 U/g bahan kering (BK) dan kadar glukosa sebesar 247,33 
$\mathrm{mg} / \mathrm{g}$ BK pada hari ke 14. Proses fermentasi dengan A. niger iradiasi sinar gamma (500 Gy) mampu meningkatkan kandungan proein kasar, acid detergent fiber (ADF), neutral detergent fiber (NDF) dan bahan kering, namun menurunkan kandungan lemak kasar dan bahan organik (BO). Hasil fermentasi dalam cairan rumen dari jerami padi fermentasi dengan dengan A. niger iradiasi sinar gamma (500 Gy) menunjukkan nilai $\mathrm{pH}$ sebesar 7,01; konsentrasi ammonia dan volatile fatty acid (VFA) masingmasing sebesar 3,92\% dan $4,73 \mathrm{mmol} / 100$.

\section{UCAPAN TERIMA KASIH}

Penulis mengucapkan terima kasih kepada DIPA PAIR BATAN yang telah membantu dana penelitian sehingga penelitian berlangsung dengan baik serta kepada Teguh Wahyono, Edi Irawan, Adul dan Udin yang telah membantu dalam pelaksanaan kegiatan penelitian ini.

\section{DAFTAR PUSTAKA}

1. Kumar, A., Gaind, S. dan Nain, L., Evaluation of thermophilic fungal consortium for paddy straw composting. Biodegradation, vol. 19, pp. 395-402, 2008.

2. Jahromi, M.F., Liang, J.B., Rosfarizan, M., Goh, Y.M., Shokryazdan, P., and Ho, Y.W., Effects of A. niger (K8) on nutritive valeu of rice straw. Afr. $J$. Biotechnol., vol. 9, no. 42, pp. 70437047, 2010.

3. Singhania, R.R., Patel, A.K., Soccol, C.R., and Pandey, A., Recent Advances in solid state fermentation. Biochem. Eng. J., vol. 44, pp. 13-18, 2009.

4. Gunam, I.B.W., Aryanta, W.R., dan Darma, I.B.N.S., Produksi selulase kasar dari kapang Trichoderma viride dengan perlakuan konsentrasi substrat ampas tebu dan lama fermentasi. J. Biologi, vol. 2, pp. 29-33, 2011.

5. Afify, A.E.M.R., Abo El Seoud M., Ibrahim, G.M., Helal, I.M.M., dan Kassem, B.W.,
Explosing of Trichoderma sp. to gamma radiation for stimulating it's pestiside Biodegradation Activity. J. Rad. Res. Appl. Sci, vol. 2, pp. 440-454, 2012.

6. Pensupa, N., Jin, M., Kokolsi, M., dan Archer, D.B., A solid state fungal fermentation based strategy for the hydrolisis of wheat straw. Bioresource Technology, vol. 149, pp. 261-267, 2013.

7. Miller J. Experiments in Molecular Genetics. New York: Cold Spring Harbor Laboratory, 1972.

8. Nelson, N., A photometric adaptation of the somogyi method for the determination of glucose. J. Biol. Chem, vol. 153, pp. 375-380, 1944.

9. Somogy, M.. Notes on sugar determination. J. Biol. Chem, vol. 195, pp. 19-23, 1952.

10. Hamzah, A., Zarin, M.A. dan Hamid A.A., Optimal physical and nutrient parameters for growth of Trichoderma virens. Sains Malaysiana, vol. 41, pp. 71-79, 2012.

11. Sudarmadji, S., Haryono, B., dan Suhardi, Prosedur Analisa untuk Bahan Makanan dan Pertanian, Yogyakarta, Liberty, 1997.

12. Krishnamoorthy, U., RCA Training Workshop on In Vitro Techniques for Feed Evaluation, April 23-27 . The International Atomic Energy Agency: Jakarta (ID): 17, 2001.

13. Kjeldahl, J., A new method for the estimation of nitrogen in organic compounds, $J$. Anal. Chem, vol. 22, pp. 366, 1883.

14. AOAC. Official Method of Analysis. Maryland: Association of Official Analytical Chemist, 2005.

15. Betiku, E., Oluoti, K.O., Solomon, B.O., Effect of Gamma Irradiation on the Hydrolysis of Lignocellulosic Materials using Cellulase derived from A. niger, 
International J. of Biotechnology and Biochemistry, vol. 6, no. 6, pp. 833-840, 2010.

16. Al masri, M.R., dan Zarkawi, M., Effect of gamma irradiation on cell-wall constituents of some agricultural residues, Radiat. Phys. Chem, vol. 44, pp. 661-663, 1994.

17. Gumilang, A.J., Kristianto, F., Juliasti S.R., Nuniek, H., dan Sumarno, Penurunan kadar lignn dari tandan kosong kelapa sawit (TKKS dan pemecahan material selulosa untuk pembentukan glukosa dengan proses fungal treatment. Paper. Fakultas Teknologi Industri, Institut Teknologi Sepuluh Nopember (ITS), Surabaya, 2014.

18. Fardiaz, S. Mikrobiologi Pangan. Bogor: IPB Press, 1992.

19. Bailey, J.E., dan Ollis, D.F. Biochemical Engineering Fundamentals. $2^{\text {nd }}$ editon,
New York: McGraw-Hill, New York, USA, 1986.

20. Ghaffar, S.H., dan Fan, M, Lignin in Straw and Its Application as an adhesive. Int. J. Adhes. Adhes, vol. 48, pp. 92-101, 2014.

21. Velasquez, A., Marnet, P.G., dan Arias, R., Improvement in nutritional quality of fibrous food via in vitro digestion by A. niger, Cien. Inv. Agr., vol. 42, no. 1, pp. 45-55, 2015.

22. Weimer, P.J., Waghorn, G.C. dan Merten, S. Effect of diet on population of three species of ruminal cellulolytic bacteria in lactatin dairy cows. J. Dairy Sci. Vol. 82, pp. 122-134, 1999.

23. Kalbande, V.H. dan Thomas, C.T. Effect of feeding bypass on rumen fermentation profile of crossbred cows. Asian-Aust. J. Anim. Sci. Vol. 14, pp. 974-978. 